\title{
The controversial Third Reich history of Hans Creutzfeldt: was he a supporter or just another adept of the "hand washing policy"?
}

A controversa história do terceiro reich de Hans Creutzfeldt: seria ele um apoiador ou apenas outro adepto da "política de lavagem das mãos"?

Paulo Eduardo Mestrinelli CARRILHO', Ricardo NITRINI²

\begin{abstract}
Creutzfeldt-Jakob disease (CJD) is a transmissible spongiform encephalopathy whose initial description is associated with two German authors, Alfons Maria Jakob and Hans Gerhard Creutzfeldt. As polemic as the issue about the Creutzfeldt's merit in the first description of the disease, is his history during the Third Reich. Some evidence pointed to the idea that he was essentially against the Nazi ideology, though some did not. He was an official member of the SS, but his own wife was convicted by a Nazi court. Some authors have argued that Creutzfeldt helped save many patients during Aktion T4 operation, but, in fact, he could have done more. Even during the post-war period, he sent a letter to authorities reporting the name of a Nazi physician who worked as a medical reviewer at the euthanasia court, but he did not proceed any further when his letter initially failed to start an investigation.
\end{abstract}

Keywords: Creutzfeldt-Jakob Syndrome; National Socialism; History.

RESUMO

A doença de Creutzfeldt-Jakob (DCJ) é uma encefalopatia espongiforme transmissível, cuja descrição original está associada ao nome de dois autores alemães, Alfons Maria Jakob e Hans Gerhard Creuztfeldt. Tão polêmica quanto a questão sobre o real mérito de Creutzfeldt na primeira descrição da doença, é sua história de vida durante o Terceiro Reich. Algumas evidências apontavam para a ideia de que ele era essencialmente contra a ideologia nazista, mas outras não. Ele foi um membro oficial da SS, mas sua própria esposa foi condenada por um tribunal nazista. Alguns autores têm argumentado que Creutzfeldt ajudou a salvar muitos pacientes durante a operação Aktion T4, mas, na verdade, ele poderia ter feito muito mais. Mesmo durante o período pós-guerra, ele enviou uma carta às autoridades revelando o nome de um médico nazista que havia se empregado como revisor médico na corte sobre eutanásia, mas ele não insistiu mais quando sua carta inicialmente não desencadeou uma investigação.

Palavras-chave: Síndrome de Creutzfeldt-Jakob; Socialismo Nacional; História.

\section{INTRODUCTION}

Walther Spielmeyer first used the term CreutzfeldtJakob disease (CJD) because two German neuropathologists had previously described the disease ${ }^{1,2}$. Alfons Maria Jakob described a series of six patients with spasticity and progressive dementia associated with neural degeneration in the early 1920s, as did Hans Gerhardt Creutzfeldt (Figure 1), who had independently published the case of a "not so" similar patient. Jakob credited Creutzfeldt for first describing the syndrome, without realizing he had also uncovered the new syndrome ${ }^{2,3}$. CJD is the usual eponym used, since Creutzfeldt certainly gave the earlier account. But, in view of Jakob's greatest contribution, many authors reasonably argued that the correct designation should be Jakob-Creutzfeldt disease $^{2,4,5}$. One ${ }^{5}$ had reported, in his own words, that: "Dr. Creutzfeldt after the II World War (WWII) told me that his case did not bear any resemblance to the cases described by Jakob". Particularly in Brazil, the use of "Jakob-Creutzfeldt Disease" is common, instead of CJD. It is also probably due to the prominent figure that doctor Jakob represented for Brazil. From May to July 1928, he gave a 20-lecture course in

${ }^{1}$ Universidade Estadual do Oeste do Paraná, Faculdade de Medicina, Cascavel PR, Brazil.

Universidade de São Paulo, Faculdade de Medicina, Departamento de Neurologia, São Paulo SP, Brazil.

Paulo Eduardo Mestrinelli CARRILHO (iD https://orcid.org/0000-0002-9457-4456; Ricardo NITRINI (D) https://orcid.org/0000-0002-5721-1525

Correspondence: Paulo Eduardo Mestrinelli Carrilho; E-mail:pemcarrilho@gmail.com

Conflict of interest: There is no conflict of interest to declare.

Authors' contributions: Carrilho PEM: main author and writer; Nitrini R: reviewer and corrections.

Received on June 18, 2020; Accepted on July 19, 2020. 


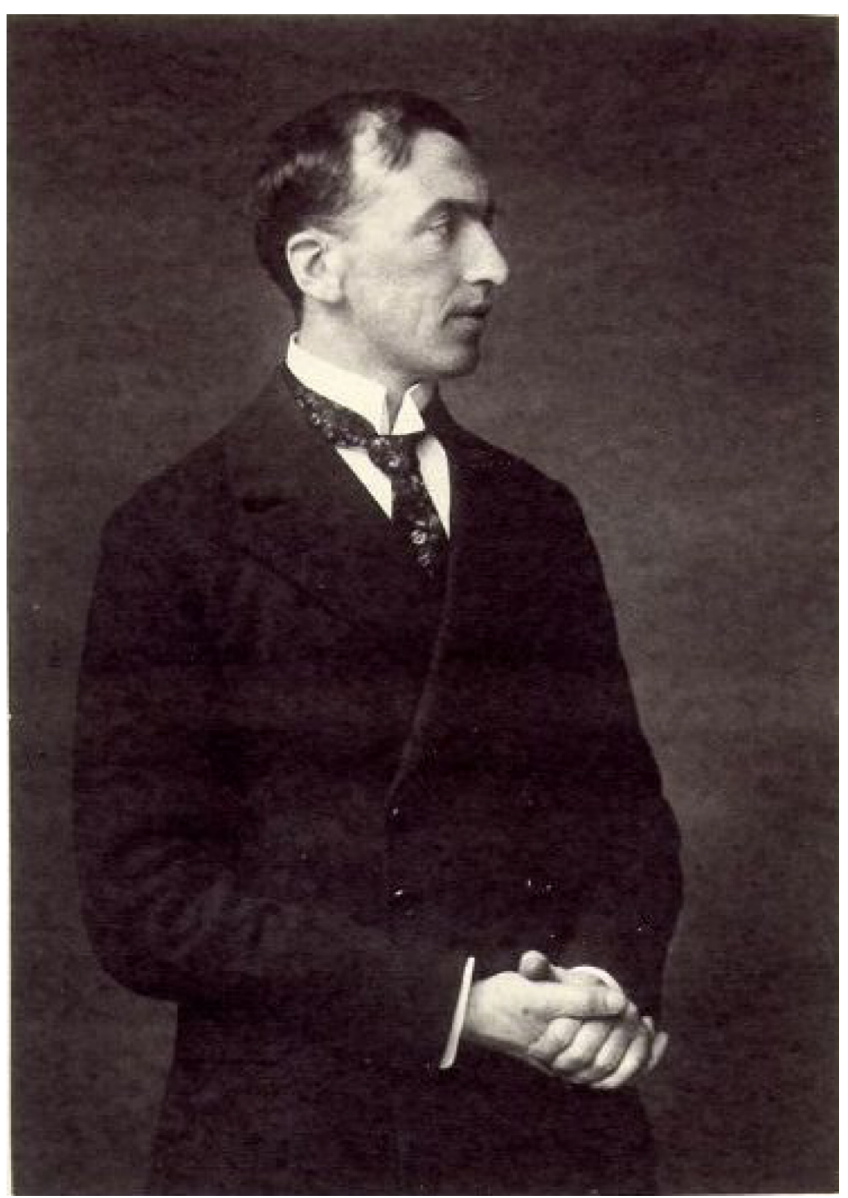

Source: Wikipedia.

Figure 1. Hans Gerhardt Creutzfeldt (1920); author unknown (public domain).

\section{CREUTZFELDT'S BRIEF HISTORY}

Creutzfeldt was born into a medical family in Harburg, a city annexed to Hamburg since 1937, on June $2^{\text {nd }}$, 1885. In 1903, he was drafted into the German army and was stationed in Kiel ${ }^{9}$. Afterward, he attended the Medicine School of the University of Jena and the University of Rostock, receiving his doctorate in $1909^{2}$. In the following years until 1912, he sought adventure as a ship's surgeon, voyaging the Pacific Ocean, taking the opportunity to study local crafts, linguistics, and tropical plants ${ }^{9}$. After returning, he worked at the Neurological Institute in Frankfurt am Main and at the psychiatric-neurological clinics in Breslau, with professor Alzheimer, and then in Kiel, after in Berlin, and finally at the Deutsche Forschungsanstalt für Psychiatrie in Munich?.

During World War I (WWI), he was a German naval medical officer. He was deployed as a reserve medical officer and survived the sinking of the auxiliary cruiser SMS Greif (Figure 2). After being captured, he was repatriated and served in the Imperial Navy until the end of the war in $1918^{9}$.

After WWI, Creutzfeldt worked with Spielmeyer in Munich and with Siemerling in Kiel². He moved to the Charité Hospital in Berlin and, after 14 years, he returned to Kiel in 1938 to become Emeritus Professor and Director of the Psychiatric and Neurological Division ${ }^{9,10}$. Then, 1939 arrived and WWII began.

\section{THE AMBIVALENT RELATIONSHIP WITH NAZISM}

During the years spent in Berlin and his subsequent time in Kiel, Creutzfeldt adopted a reserved but not completely hostile attitude to Nazism 9 . He was a registered candidate for the National Socialist German Doctors' Association, a paying member of the SS and Deputy Medical Assessor at the Berlin High Court of Hereditary Health ${ }^{9}$. However, he was one of just two members of Kiel's school of medicine who did not join the Nazi Party ${ }^{10}$. He was politically inconspicuous, with no emotional attachment to the ideology ${ }^{9,13}$. He also did not categorically reject compulsory sterilization in the reports he was required to produce and accepted that chronically ill patients who were unavoidably transferred to state hospitals for long-term treatment faced the threat of being sent to death camps for Aktion T4, 14,15 (Chart 1). During WWII, as a Clinic Director in Kiel, of 605 patients transferred from Kiel, 135 were deported and 65 of these are known to having been murdered (the true figure is likely to be over 100) $)^{9}$. Nevertheless, Creutzfeldt claimed that he was "a decided opponent of the murder of the psychiatrically ill", 10,14 and one psychiatrist once declared that he was known to have attacked "euthanasia" during his lectures ${ }^{10}$, declaring that "They are murderers!" 


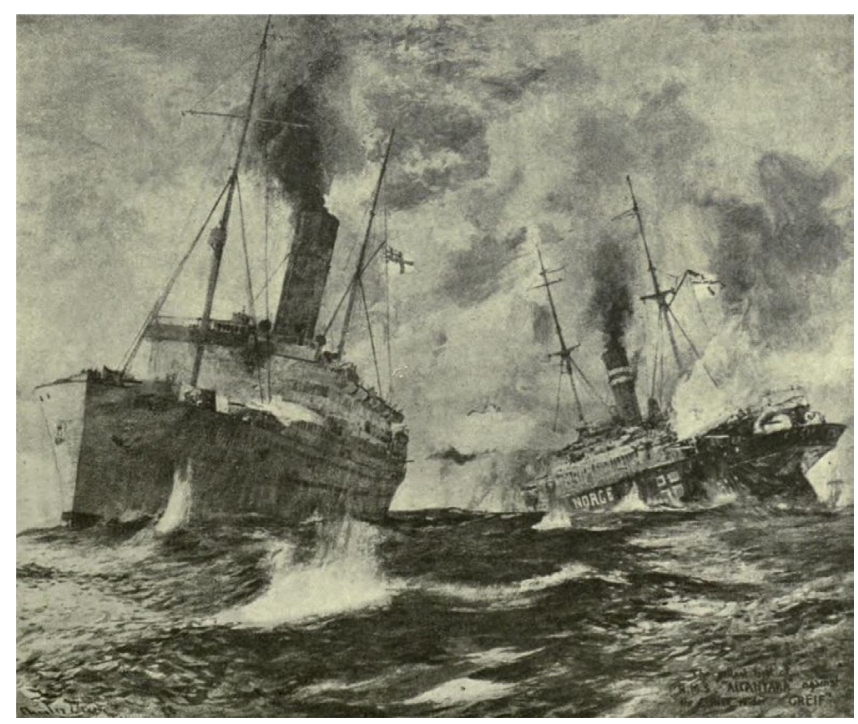

Source: Wikipedia.

Figure 2. HMS Alcantara engages the German raider Grief on 29 February 1916, in the North Sea. Both ships sank. SS Grief was Creutzfeldt's warship in World War I (public domain).
The Aktion T4 operation was a postwar name for mass murder by involuntary euthanasia in Nazi Germany. The name

$T 4$ is an abbreviation of Tiergartenstraße 4, a street address of the Chancellery department set up in early 1940, in the

Berlin borough of Tiergarten, which recruited and paid personnel associated with T4. Certain German physicians were authorized to select patients "deemed incurably sick, after most critical medical examination" and then administer them a "merciful death". "Merciful killings" referred to the systematic extermination of certain groups including the mentally ill, aged, disabled, and others. It was an Euthanasia Program, part of the Nazis'attempt to preserve the purity of the master race - in order to create a superior group of "Aryans," the Nazis needed to destroy all those with racial defects. By the end of 1940, almost

27,000 Germans had been killed as part of the program; by August 1941, more than 35,000 more had been exterminated. Aktion T4 was officially closed down on September 1, 1941, due

to growing public pressure, including a sermon delivered by Bishop Clemens Galen in Muenster on August $3^{\text {rd }}$. However, the Nazis secretly continued their "merciful killings" all the way up to the end of the war.

Source: Proctor ${ }^{16}$ and Shoah Resource Center, the International School for Holocaust Studies ${ }^{17}$.
His luck was that some Nazis thought him very eccentric or even "a little mad" ${ }^{10}$. However, it was not consistent with his lack of energy in the prevention of such murders ${ }^{9}$. Another event, which reinforced this idea, occurred when he put a great effort into reversing the conviction of a soldier in 1941/1942 who had deserted, which led to an avoidable death sentence ${ }^{14,15}$.

However, worth mentioning, is the fact that, during the war, bombing raids destroyed his home and clinic ${ }^{11}$. Besides, in 1943, a court sentenced his wife, Cläre, to four years in prison for spiteful and malicious remarks against the Third Reich ${ }^{11}$. Noteworthy, his son, Harald, defected from the German navy to join the Dutch underground resistance ${ }^{12}$.

Finally, another ambivalent event occurred years after WWII. In 1955, Creutzfeldt informed the President of the Court in Schleswig Holstein that the Nazi physician, Werner
Heyde, was employed as a medical reviewer at the court. Interestingly, Creutzfeldt did not proceed any further when his letter initially failed to start an investigation into Heyde's case $^{9,12,13}$. One year after, doctor Creutzfeldt retired and, on December $30^{\text {th }}, 1964$, he died at the age of 80 , after a longlasting disease $\mathrm{e}^{2,9}$.

It is difficult to consider that Creutzfedt was a clear adept of the Third Reich ideology. However, it is also nonsense to deny that some of his attitudes and passive behaviors put in check this belief. In general, his declared position seemed to be against the Third Reich, but some controversy has recently emerged, according to some authors ${ }^{9,13,14,15}$. Nevertheless, the actual question remains the same: Was he head-on against the Nazi ideology or was he merely another person who washed his hands? Only more historical research could shed light on this issue.

\section{References}

1. Henry R, Murphy FA. Etymologia: Creutzfeldt-Jakob Disease. Emerg Infect Dis. 2017 Jun;23(6):956. https://doi.org/10.3201/eid2306. ET2306

2. Pearce JMS. Jakob-Creutzfeldt Disease. Historical Note. Eur Neurol. 2004 Nov;52(3):129-31. https://doi.org/10.1159/000081462

3. Masters CL, Gajdusek DC. In: Smith WT, Cavanagh JB (eds.). Recent advances in neuropathology. v. 2. Edinburgh: Churchill Livingstone; 1982. p.139-63

4. Katscher F. It's Jakob's disease, not Creutzfeldt's. Nature. 1998 May;393(6680):11. https://doi.org/10.1038/29862

5. Manuelidis EE. Creutzfeldt-Jakob disease. J Neuropathol Exp Neurol. 1985 Jan;44(1):1-17. https://doi.org/10.1097/00005072198501000-00001
6. Triarhou LC. Alfons Maria Jakob (1884-1931), neuropathologist par excellence. Scientific endeavors in Europe and Americas. Eur Neurol. 2009 Nov;61(1):52-8. https://doi.org/10.1159/000175123

7. De Muñoz PFN. À luz do biológico: psiquiatria, neurologia e eugenia nas relações Brasil-Alemanha (1900-1942). Thesis (Doctorate in History of Health Sciences). Rio de Janeiro: Fundação Oswaldo Cruz; 2015.

8. Cipriani G, Dolciotti C, Pichi L, Bonucelli U. Alzheimer and his disease: a brief history. Neurol Sci. 2011 Apr;32(2):275-9. https://doi. org/10.1007/s10072-010-0454-7

9. Wolf JH, Foley P. Hans Gerhard Creutzfeldt (1885-1964): a life in neuropathology. J Neural Transm (Vienna). 2005 Aug;112(8):I-XCVII. https://doi.org/10.1007/s00702-005-0288-2 
10. Lifton RJ. The Nazi doctors: medical killing and the psychology of genocide. New York: Basic Books, Inc., Publishers; 1986.

11. Strous RD, Edelman MC. Eponyms and the Nazi era: time to remember and time for change. Isr Med Assoc J. 2007 Mar;9(3):207-14.

12. Zeidman LA. Neuroscience In Nazi Europe Part li. Can J Neurol Sci. 2011 Nov;38(6):826-38. https://doi.org/10.1017/s0317167100012397

13. Kondziella D. Thirty neurological eponyms associated with the Nazi era. Eur Neurol. 2009 Jun;62(1):56-64. https://doi. org/10.1159/000215880
14. Kondziella D, Zeidman LA. What's in a name? Neurological eponyms of the Nazi era. Front Neurol Neurosci. 2016 Apr;38:184-200. https:// doi.org/10.1159/000442683

15. Illert M, Schmidt M. Hans Gerhardt Creutzfeldt (1885-1964) in the Third Reich. A reevaluation. Neurology 2020 Jun;95:72-76. doi:10.1212/WNL.0000000000009785

16. Proctor RN. Racial hygiene: medicine under the Nazis. Cambridge, MA: Harvard College; 1988.

17. Shoah Resource Center, The International School for Holocaust Studies. Available from: www.yadvashem.org 